DOI: $10.17805 /$ zpu.2015.2.30

\title{
Использование метода семантического дифференциала в исследовании представлений юношей и девушек о семье
}

\author{
О. В. АЛМАЗОВА, В. П. ДЗУКАЕВА, Т. Ю. САДОВНИКОВА \\ (МОСКОВСКИЙ ГОСУДАРСТВЕННЫЙ УНИВЕРСИТЕТ ИМ. М. В. ЛОМОНОСОВА)
}

В статье описан опыт использования модифицированного варианта методики «Семантический дифференциал» в исследовании образов родительской и своей будущей семьи у юношей и девушек.

В исследовании 2013-2014 гг. приняли участие 205 студентов (61 юноша и 144 девушек) вузов и ссузов в возрасте от 17 до 24 лет, 108 студентов $(52,7 \%)$ русской национальности и 97 студентов (47,3\%) осетинской национальности (гг. Москва, Владикавказ и Алагир). В качестве основного метода исследования был использован модифицированный вариант метода семантического дифференциала (Е. Ю. Артемьева, В. Ф. Петренко), способ анализа данных предложен О. В. Алмазовой.

Как выяснилось, оценки студентами образа своей будущей семьи значимо более позитивные по сравнению с оценками образа родительской семьи. Выявленные особенности представлений о родительской и своей будущей супружеской семье имеют значимые гендерные и этнокультурные различия. Девушки больше используют характеристики, которые принято считать скорее эмоциональными, феминными, например «теплая» и «мягкая». Юноши - характеристики, которые традиционно считаются маскулинными, например «сильная». Гендерные различия в представлениях о будущей супружеской семье проявились в более позитивных ее оценках девушками.

Выявлены как инвариантные, так и культурно-специфические особенности образов родительской и будущей супружеской семьи у студентов, являющихся представителями различных культур - русской и осетинской. Сходство проявилось в подобии семантических профилей образов семьи, более высоких средних оценках образа “Моя будущая семья» по сравнению с оценками образа «Наша семья» (родительская). Различия в оценках студентами образов родительской и будущей супружеской семьи проявились в том, что русские студенты больше ориентированы на ценности культуры современного типа (по Дж. Таунсенду), а осетинские - традиционной культуры.

Ключевые слова: юношеский возраст, семья, семантический дифференциал, кросскультурное исследование, отношение к браку, образ родительской семьи, образ будущей супружеской семьи.

\section{ВВЕАЕНИЕ}

Ю ношеский возраст является центральным этапом становления идентичности (Erikson, 1968). Одной из главных задач развития данного периода становится перестройка взаимоотношений с родителями (А. Аепсли, Р. Хевигхерст (Havighurst, 1972), И. С. Кон, А. С. Спиваковская, Э. Г. Эйдемиллер, А. Я. Варга и др.). Изучение процесса психологического отделения от родительской семьи имеет длительную историю в отечественной и в зарубежной психологии на протяжении ХХ в. (3. Фрейд, М. Малер, П. Блос, Аж. Хоффман, Р. Ажосселсон, М. Элисон, Р. Сабателли и др.).

В отечественной психологии внимание проблеме сепарации от родителей, которая за пределами детских периодов развития понимается как процесс психологического и часто физического (отъезд из родительского дома) отделения от родителей, уделялось в контексте проблематики субъектности человека (Петровский, Ярошевский, 1998; Абульханова, 1999; Брушлинский, 2003; Шабельников, 2006), зрелости личности (Фельдштейн, 1995; Бодалев, 1998; Гамезо и др., 1999), суверенности личности (Нартова-Бочавер, 2008). Эмпирические исследования и психотерапевтическая практика 
объективируют сложности взаимоотношений взрослеющих детей и их родителей (Варга, 2009; Садовникова, 2009; Манухина, 2011; Коновалова, 2012: Электр. ресурс).

Процесс сепарации на этапе перехода от детства к взрослости включает в себя деидеализацию родителей (Блос, 2010), смену значимых лиц (Кон, 1979), формирование образа мира (Буровихина, 2013) и др. Задача перестройки детско-родительских отношений в юношеском возрасте включает в себя и задачу построения индивидуальных представлений о родительской и своей будущей супружеской семье (Ипполитова, 2011).

Представленное исследование является частью работы, направленной, в частности, на решение задачи интеграции понятия «психологическая сепарация», широко используемого в исследованиях становления личности в подростковом и юношеском возрасте в зарубежной психологии, в систему понятий отечественной психологии развития (Blos, 1979; Hoffman, 1984; Lapsley et al., 1989; Kagitcibasi, 2005; Barrera et al., 2011; Психология и культура, 2003; Берри и др., 2007).

Цель представленного в статье исследования - выявление образов родительской семьи и будущей супружеской семьи у юношей и девушек. Аля этого мы использовали модифицированный метод семантического дифференциала (СА). Описание полученных данных проводилось в соответствии со схемой, предложенной в работе О. В. Алмазовой (Алмазова, 2013: Электр. ресурс).

В отечественной психологии первой использовала метод СА Е. Ю. Артемьева (Артемьева, 1999). Метод психосемантического анализа широко используется отечественными исследователями для изучения семантико-перцептивных универсалий и личностно-смысловых установок (Шмелев, 2002), Аинамики общественного сознания (Петренко, Митина, 2012), мужской и женской гендерной идентичности (Перегудина, 2011), образа семьи (Ипполитова, 2011), представлений психосоматических больных о счастье (Виничук, 2012: Электр. ресурс), отношения ко времени (Аенисова, 2013), особенностей образа взрослого сиблинга (Алмазова, 2013: Электр. ресурс) и др. В задачу психосемантики, согласно В. Ф. Петренко, входит реконструкция индивидуальной системы значений, через призму которой происходит восприятие мира, других, самого себя (Петренко, 2005).

В исследовании, проведенном в 2013-2014 гг., приняли участие 205 студентов, 61 юноша и 144 девушки; представители русской национальности - 108 чел. (52,7\%) и 97 чел. (47,3\%) (26 юношей $(26,8 \%)$ и 71 девушка $(73,2 \%))$ - представители осетинской национальности из Москвы, а также Владикавказа и Алагира (Республика Северная Осетия - Алания). Возраст участников - от 17 до 24 лет.

Метод СА применялся для сравнительного исследования образов своей родительской и будущей супружеской семьи с помощью предложенного набора шкал-антонимов. Респондентам предлагалось оценить родительскую и свою будущую супружескую семью по девяти парам прилагательных: слабый - сильный, тяжелый - легкий, пассивный - активный, холодный - теплый, мягкий - твердый, гладкий - шершавый, простой - сложный, влажный - сухой, обыденный - праздничный.

За основу были приняты шкалы антонимов, предложенные в классическом варианте СА (Артемьева, 1999), дополненные шкалами из исследования О. В. Алмазовой (Алмазова, 2013: Электр. ресурс) и выполненные в дипломной работе М. С. Борлаковой под руководством Т. Ю. Садовниковой. Отметим еще раз, что выбор данного метода был обусловлен желанием увидеть не только осознаваемые, но и неосознаваемые черты сходства и различия в образах родительской и будущей супружеской семьи у студентов. 
В инструкции испытуемых просили сначала выбрать из каждой пары то прилагательное, которое наиболее подходит для оценки определенного представления, а затем указать степень выраженности качества от 0 до 3 баллов: 0 баллов - затрудняюсь ответить, 1 - малая выраженность, 2- средняя выраженность, 3- сильная выраженность. В инструкции рекомендовалось избегать ответа «0».

\section{ОСОБЕННОСТИ ОБРАЗОВ РОАИТЕАЬСКОЙ \\ И БУАУЩЕЙ СУПРУЖЕСКОЙ СЕМЬИ \\ У СТУАЕНЧЕСКОЙ МОАОАЕЖИ}

Были выявлены особенности образов «Наша семья» (родительская), «Моя будущая семья» (супружеская) у юношей и девушек. Метод СА, по сути, является проективной методикой (Родионова, 1996; Косаревская, Кутькина, 2009) и дает возможность выявить не только осознаваемые, но и неосознаваемые черты сходства и различия в образах родительской и будущей супружеской семьи. На первом шаге анализа данных были выявлены качества-универсалии. Семантическими универсалиями называют качества, на которые указывают более 75\% выборки (Серкин, 2004). Учитывая данный факт, выбрав только полюса, мы получили результаты, описанные кратко ниже.

Аля образа «Наша семья» (родительская) универсалиями являются следующие прилагательные из шкал-антонимов (см. выше): «сильная» $(80,4 \%)$, «мягкая» $(75,3 \%)$ и на уровне тенденции - «теплая» $(73,2 \%$ ) (в скобках указан процент испытуемых, которые выбрали данное прилагательное для характеристики образа «Наша семья»). Аля образа «Моя будущая семья» (супружеская): «сильная» $(93,3 \%)$, «легкая» $(75,8 \%)$, «активная» $(80,6 \%)$, «теплая» $(86,6 \%)$, «мягкая» $(82,4 \%)$, «праздничная» $(79,9 \%)$ и на уровне тенденции «гладкая» $(73,7 \%)$.

Родительская семья оценивается как «сильная» и «мягкая», в то время как оценка будущей супружеской семьи включает значительно больше положительных качеств: «сильная», «легкая», «активная», «теплая», «мягкая», «праздничная».

Можно видеть, что число ожиданий (т. е. фактически требований) к своей будущей супружеской семье оказывается большим, чем число характеристик-универсалий для родительской семьи. Идеальный образ является ориентировкой в желаемых свойствах своей супружеской семьи. Влияние отношений с родителями на особенности партнерских и супружеских отношений личности отмечали многие исследователи (3. Фрейд, К. Г. Юнг, Э. Берн и др.). Выделены две основные стратегии построения ролевой структуры супружеской семьи: повторение родительского сценария или построение семьи по принципу противоположности родительскому образцу (Ю. Е. Алешина, Э. Г. Эйдемиллер, В. В. Юстицкис). В работе С. И. Голода выделено три исторических типа семьи: патриархальный (традиционный), детоцентристский (современный), супружеский (постсовременный) (Голод, 1995). Супружеская семья характеризуется неинституциональностью характера связи супругов, симметричностью их прав и обязанностей, включением в ценности семьи автономии личности, свободы выбора и уважения права партнера на этот выбор. Аанные современных российских исследований (Н. Н. Аидовская, Н. Ю. Рыжова, Н. С. Шипова, Н. О. Белорукова, Т. А. Крюкова и др.) указывают на выраженную тенденцию появления новых типов семей, трудности совладания с ситуациями разочарования в отношениях с партнером, неудовлетворенность браком. Семейный союз, правила конкретной семьи все больше становятся уникальным результатом жизнедеятельности пары, семейные сценарии (С. Минухин) все более индивидуализированы. Мы предполагаем, что именно набор 
универсалий в идеальном образе семьи, который не совпадает с набором универсалий Аля родительской семьи, определяет индивидуальную «ценность» будущей супружеской семьи.

В табл. 1 представлены средние значения оценок, полученных по ответам студентов, по каждой из пар прилагательных для образов «Наша семья» и «Моя будущая семья» в методике СА. Отметим существенное сходство общего профиля оценок родительской семьи и будущей супружеской семьи (представим мысленно приведенные числовые данные в виде графических профилей). Выявлены корреляционные связи на значимом уровне $(\mathrm{p} \leq 0,001)$ для оценок всех девяти пар прилагательных-антонимов, характеризующих образы «Наша семья» и «Моя будущая семья». Значения коэффициентов корреляции находятся, в основном, в диапазоне $r=0,4-0,6$ (коэффициент Спирмена), что принято считать средним уровнем связи параметров (А. А. Наследов, И. С. Клецина). Представление о механизмах формирования образа будущей семьи и полученные данные статистического анализа подтверждают гипотезу о трансляции образа семьи.

СРЕАНИЕ ЗНАЧЕНИЯ ОЦЕНОК ПО КАЖАОЙ ИЗ ПАР ПРИААГАТЕАЬНЫХ Таблица 1 АИЯ ОБРАЗОВ «НАША СЕМЬЯ» И «МОЯ БУАУЩАЯ СЕМЬЯ» (АИЯ ВСЕЙ ВЫБОРКИ)

AVERAGE VALUES OF AN ASSESSMENT FOR EACH COUPLE OF ADJECTIVES Table 1

(THE IMAGES OF “OUR FAMILY” AND “MY FUTURE FAMILY”, FOR THE WHOLE SAMPLING)

\begin{tabular}{|l|c|c|c|c|}
\hline \multirow{2}{*}{\multicolumn{1}{|c|}{ Пары прилагательных }} & \multicolumn{2}{|c|}{ «Наша семьл» } & \multicolumn{2}{|c|}{ "Моя будушая семья» } \\
\cline { 2 - 5 } & среднее & $\begin{array}{c}\text { станд. } \\
\text { откл. }\end{array}$ & среднее & $\begin{array}{c}\text { станд. } \\
\text { откл. }\end{array}$ \\
\hline Слабый - сильный & 2,02 & 1,49 & 2,55 & 0,97 \\
Тяжелый - легкий & 0,47 & 1,96 & 1,57 & 1,54 \\
Пассивный - активный & 1,29 & 1,84 & 2,31 & 1,12 \\
Холодный - теплый & 1,57 & 1,78 & 2,44 & 0,97 \\
Мягкий - твердый & $-1,04$ & 1,97 & $-1,56$ & 1,81 \\
Шершавый - гладкий & 1,02 & 1,74 & 1,85 & 1,36 \\
Сложный - простой & 0,42 & 2,13 & 1,06 & 1,76 \\
Сухой - влажный & 0,31 & 1,49 & 0,86 & 1,34 \\
Обыденный - праздничный & 0,78 & 1,95 & 1,89 & 1,39 \\
\hline
\end{tabular}

У обследованных студентов образ будущей супружеской семьи носит более позитивный характер по сравнению с образом родительской семьи. Мы сравнили оценки, данные студентами по каждой из пар прилагательных, для родительской и будущей супружеской семьи. Воспользовавшись критерием Вилкоксона для двух зависимых выборок, мы получили следующие результаты. Значимые различия $(\mathrm{p} \leq 0,002)$ выявлены при сравнении всех оценок двух образов семьи: родительской и будущей супружеской.

Образ «Моя будущая семья» у юношей и девушек представлен значимо более высокими оценками по всем девяти прилагательным, а именно: «сильная», «легкая», «активная», «теплая», «мягкая», «гладкая», «простая», «влажная», «праздничная», 
являющимися «положительным» полюсом соответствующих биполярных шкал прилагательных, используемых в СА, по сравнению с образом «Наша семья», отражающим восприятие (осознаваемое и неосознаваемое) родительской семьи.

Мы считаем, что полученные результаты, с одной стороны, свидетельствуют об идеализации будущей супружеской семьи студентами, с другой - отражают феномен трансляции паттернов семейного функционирования и ядерные характеристики семьи как системы (М. Боуэн, Э. Г. Эйдемиллер, А. Б. Шнейдер и др.).

\section{ГЕНАЕРНЫЕ РАЗАИЧИЯ ОБРАЗА СЕМЬИ

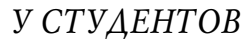

Аалее мы выделили универсалии для образов «Моя будущая семья» (супружеская) «Наша семья» (родительская) отдельно для юношей и отдельно для девушек.

Прилагательными, которые выбрали более $75 \%$ выборки студентов разного пола (Серкин, 2004) для образа «Наша семья» (родительская), оказались следующие (в скобках указан процент девушек или юношей, выбравших данное прилагательное при оценке образа). У юношей — «сильный» $(81 \%)$ и на уровне тенденции — «мягкий» $(74,1 \%)$. У девушек для образа «Наша семья» универсалиями выступили прилагательные «сильный» $(80,1 \%)$, «теплый» $(75,7 \%)$, «мягкий» $(82,4 \%)$.

Универсалиями для образа «Моя будущая семья» (супружеская) оказались для юношей: «сильный» $(86,2 \%)$, «активный» $(75,9 \%)$ и на уровне тенденции - «теплый» $(74,1 \%)$ и «влажный» $(70,7 \%)$. Аля девушек при оценке образа «Моя будущая семья» универсалиями стали прилагательные «сильный» $(96,3 \%)$, «легкий» $(81,6 \%)$, «активный» $(91,2 \%)$, «теплый» $(91,9 \%)$, «мягкий» $(88,1 \%)$, «гладкий» $(80,9 \%)$ и «праздничный» $(84,6 \%)$.

При анализе гендерных особенностей образов семьи как родительской, так и идеального образа супружеской семьи выявлены и сходства, и различия. Укажем сначала на сходства. И юноши, и девушки воспринимают родительскую семью (образ «Наша семья») как «сильную» (81,0 и 80,1\% соответственно) и «мягкую» $(74,1$ и 82,4\%), а образ своей будущей супружеской семьи как «сильной» $(86,2$ и 96,3\%), «активной» $(75,9$ и $91,2 \%)$ и «теплой» $(74,1$ и 91,9\%). Наиболее заметными различиями в восприятии юношами и девушками образов семьи мы считаем, во-первых, большее количество универсалий для обоих образов семьи (родительской и супружеской) у девушек по сравнению с юношами. Во-вторых, девушки больше используют характеристики, которые принято считать скорее эмоциональными, феминными, например «теплая» и «мягкая», а юноши - характеристики, которые традиционно считаются маскулинными, например «сильная». В-третьих, гендерные различия в образах будущей супружеской семьи проявились в более позитивных ее оценках девушками.

Отметим, что для девушек, в отличие от юношей, важными характеристиками образа будущей супружеской семьи являются прилагательные «легкая», «гладкая», «праздничная», что можно интерпретировать как важность для них гармонии в супружеских отношениях, большую ориентацию на психотерапевтичность эмоционального климата семьи.

В табл. 2 (с. 282) представлены средние значения оценок отдельно юношами и отдельно девушками образа «Наша семья» (родительская).

Оценки девушками образа «Наша семья» имеют значимо более высокие показатели, по сравнению с оценками юношей, по прилагательному «мягкая» $(\mathrm{p}=0,000)$.

В оценках девушек по сравнению с оценками юношей образ «Моя будущая семья» имеет значимо более высокие показатели по следующим прилагательным: «сильная» 


\section{СРЕАНИЕ ЗНАЧЕНИЯ ОЦЕНОК ЮНОШАМИ И АЕВУШКАМИ ОБРАЗА «НАША СЕМЬЯ» \\ Таблица 2

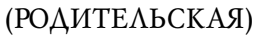

Table 2

AVERAGE VALUES OF ESTIMATES BY MEN AND WOMEN OF THE IMAGE OF "OUR FAMILY" (PARENTAL FAMILY)

\begin{tabular}{|l|c|c|c|c|}
\hline \multirow{2}{*}{\multicolumn{1}{|c|}{ Пары прилагательных }} & \multicolumn{2}{|c|}{ Юноши } & \multicolumn{2}{c|}{ Аевушки } \\
\cline { 2 - 5 } & среднее & $\begin{array}{c}\text { станд. } \\
\text { откл. }\end{array}$ & среднее & $\begin{array}{c}\text { станд. } \\
\text { откл. }\end{array}$ \\
\hline Слабый - сильный & 2,02 & 1,53 & 2,02 & 1,49 \\
Тяжелый - легкий & 0,26 & 1,96 & 0,56 & 1,96 \\
Пассивный - активный & 1,14 & 1,92 & 1,35 & 1,81 \\
Холодный - теплый & 1,42 & 1,89 & 1,64 & 1,73 \\
Мягкий - твердый & 0,14 & 2,01 & $-1,56$ & 1,72 \\
Шершавый - гладкий & 0,66 & 1,75 & 1,19 & 1,73 \\
Сложный - простой & 0,18 & 2,16 & 0,52 & 2,11 \\
Сухой - влажный & 0,26 & 1,32 & 0,33 & 1,57 \\
Обыденный - праздничный & 0,82 & 1,94 & 0,76 & 1,97 \\
\hline
\end{tabular}

$(\mathrm{p}=0,004)$, «легкая» $(\mathrm{p}=0,003)$, «активная» $(\mathrm{p}=0,020)$, «теплая» $(\mathrm{p}=0,000)$, «мягкая» $(\mathrm{p}=0,000)$, «гладкая» $(\mathrm{p}=0,000)$, «простая» $(\mathrm{p}=0,002)$, «влажная» $(\mathrm{p}=0,006)$, «праздничная» $(\mathrm{p}=0,002)$. Полученный результат мы связываем с известными психоәмоциональными гендерными различиями на этапе юности (Е. П. Ильин, И. Г. Малкина-Пых, И. С. Клецина и др.).

\section{КРОСС-КУАЬТУРНЫЕ РАЗАИЧИЯ В ОБРАЗАХ РОАИТЕАЬСКОЙ И БУАУЩЕЙ СУПРУ ЖЕСКОЙ СЕМЬИ У СТУДЕНТОВ}

Аалее мы выделили универсалии в образах семьи, родительской и будущей супружеской, у студентов представителей двух культур: русской и осетинской.

При сравнении универсалий для образа «Наша семья» (родительская) обращает на себя внимание сходство в оценках, данных русскими и осетинскими студентами. Аля характеристики родительской семьи и русскими, и осетинскими студентами наиболее часто используется прилагательное «сильный» $(76,5$ и $84,4 \%$ соответственно). На уровне тенденции выделяются прилагательные «теплый» $(73,1$ и 73,3\%) и «мягкий» $(73,1$ и $77,8 \%)$ как важные характеристики родительской семьи. Различия проявились в том, что осетинские студенты, в отличие от русских, часто выделяют в качестве характеристики родительской семьи прилагательное «активная» (75,6\%).

При анализе ответов, данных русскими и осетинскими студентами вузов и ссузов при оценке образа «Моя будущая семья» (супружеская), были выделены следующие общие для респондентов двух культур характеристики: «сильный» $(98,1$ и 81,8\% соответственно), «активный» $(91,3$ и 81,1\%), «теплый» $(90,7$ и 82,2\%), «праздничный» $(81,7$ и 77,8\%). Различия проявились в том, что для русских студентов в образе «Моя буду- 
щая семья» часто используются прилагательные «легкий» $(77,9 \%)$ и «гладкий» (75,0\%). А для осетинских студентов - прилагательное «мягкий» $(92,2 \%)$. Отметим, что в образе своей будущей супружеской семьи у русских студентов чаще представлены характеристики, отражающие активную, субъектную позицию юношей и девушек, - «сильный», «активный», и характеристики, которые мы считаем возможным интерпретировать как косвенные показатели межличностных отношений в будущей семье, - «теплый», «праздничный», «легкий», «гладкий». Аля осетинских студентов наиболее часто выбираемой характеристикой будущей супружеской семьи оказалось прилагательное «мягкий». Мы предполагаем, что выявленные различия в образах родительской и будущей супружеской семьи у русских и осетинских студентов связаны с принадлежностью студентов к разным культурам. Принято считать, что осетинская культура ближе к традиционному типу культуры, где высоки ценности традиций, авторитета старшего поколения и принадлежности к семье, клану, т. е. речь идет о ценностях коллективизма.

Полученный результат, на наш взгляд, свидетельствует о выраженных ценностях личной ответственности, большей автономии русских юношей и девушек от родительской семьи. Аругими словами, больше представлены ценности индивидуализма, характерные для современного и динамически развивающегося типов культур (по Аж. Таунсенду).

В табл. 3 представлены средние значения оценок русскими и осетинами образа «Наша семья».

СРЕАНИЕ ЗНАЧЕНИЯ ОЦЕНОК РУССКИМИ И ОСЕТИНАМИ

Таблища 3 ОБРАЗА «НАША СЕМЬЯ»

Table 3

AVERAGE VALUES OF ESTIMATES BY RUSSIANS AND OSSETIANS OF THE IMAGE OF "OUR FAMILY”

\begin{tabular}{|l|c|c|c|c|}
\hline \multirow{2}{*}{\multicolumn{1}{|c|}{ Парьл прилагательных }} & \multicolumn{2}{c|}{ Руские } & \multicolumn{2}{c|}{ Oсетины } \\
\cline { 2 - 5 } & среднее & $\begin{array}{c}\text { станд. } \\
\text { откл. }\end{array}$ & среднее & $\begin{array}{c}\text { станд. } \\
\text { откл. }\end{array}$ \\
\hline Слабый - сильный & 1,79 & 1,73 & 2,03 & 1,38 \\
Тяжелый - легкий & $-0,09$ & 1,79 & 0,88 & 2,01 \\
Пассивный - активный & 0,79 & 2,03 & 1,46 & 1,87 \\
Холодный - теплый & 1,21 & 1,94 & 1,67 & 1,72 \\
Мягкий - твердый & $-0,91$ & 1,85 & $-1,00$ & 2,03 \\
Шершавый - гладкий & 0,65 & 1,69 & 1,06 & 1,83 \\
Сложный - простой & 0,12 & 2,03 & 0,43 & 2,19 \\
Сухой - влажный & 0,09 & 1,37 & 0,20 & 1,63 \\
Обыденный - праздничный & 0,40 & 1,92 & 0,61 & 2,08 \\
\hline
\end{tabular}

Студенты осетинской национальности по сравнению с русскими студентами оценили как значимо более выраженные следующие прилагательные, характеризующие образ «Наша семья» (родительская): «легкий» $(\mathrm{p}=0,013)$, «активный» $(\mathrm{p}=0,008)$, 
«гладкий» $(\mathrm{p}=0,05)$ (использовался критерий Манна - Уитни для независимых выборок).

Образ своей будущей семьи у осетинских и русских студентов имеет как сходства, так и различия. Выявлено сходство семантических профилей образа будущей супружеской семьи. Однако студенты-осетины представляют свою будущую семью как значимо более мягкую $(\mathrm{p}=0,002)$, простую $(\mathrm{p}=0,017)$ и праздничную $(\mathrm{p}=0,011)$ по сравнению с представлениями русских студентов.

Ожидаемыми, на наш взгляд, являются выявленные различия в восприятии русскими и осетинскими студентами образов семьи: во-первых, у русских студентов более «насыщенным» является образ будущей супружеской семьи, т. е. выявлено большее число универсалий и выше значения показателей количества выборов для универсалий. У осетинских студентов, в свою очередь, больше выражен образ родительской семьи. Во-вторых, различия в образах семьи отражают большую ориентацию русских студентов на ценности культуры современного типа, в то время как ответы осетинских студентов в основном свидетельствуют о большей значимости ценностей традиционной культуры в сфере супружеских отношений. В-третьих, мы считаем важным полученный результат о сходстве семантических профилей образов родительской и супружеской семьи у юношей и девушек, представителей русской и осетинской культуры. Аругими словами, получено подтверждение инвариантной составляющей образов семьи в двух культурах.

\section{ЗАКАЮЧЕНИЕ}

Оценки студентами своей будущей семьи значимо более позитивные, по сравнению с оценками родительской семьи. Полученный результат определяется идеальным характером образа будущей супружеской семьи и соотносится с одной из главных задач развития в юношеском возрасте - задачей психологической сепарации от родительской семьи. Юноши и девушки при успешном достижении сепарации от родителей будут способны строить эмоционально близкие, доверительные, зрелые партнерские отношения в браке (Теория семейных систем ..., 2005; Варга, 2009; Сытько, 2014; Haws, Mallinckrodt, 1998; Saraiva, Matos, 2012). Гендерные различия в представлениях о родительской семье проявились в том, что девушки больше используют характеристики, которые принято считать скорее эмоциональными, феминными, например «теплая» и «мягкая». Юноши чаще используют характеристики, которые традиционно считаются маскулинными, например «сильная». Различия в представлениях о будущей супружеской семье проявились в более позитивных ее оценках девушками. Полученные различия можно объяснить тем, что создание супружеской семьи в юношеском возрасте является более значимой целью для девушек, чем для юношей.

Универсальность образов семьи испытуемых выражена в том, что семантические профили образов родительской и будущей супружеской семьи имеют высокую степень сходства соответствующих образов у респондентов юношеского возраста, принадлежащих к двум разным культурам: русской и осетинской.

Анализ норм поведения, правил, принятых в осетинском обществе, позволяет отнести его к традиционной культуре (Кибизова, 1999; Калоев, 2004). В традиционной культуре существует большая преемственность ценностей и традиций межпоколенных отношений, уважения к старшим, ценностей семьи (Верещагина, 2010; Ильченко, 2010). В русской культуре, как полагают исследователи, уровень личных свобод выше и проявление различных форм взаимодействия более открыто (Берри и др., 2007). 
Таким образом, оценки студентами своей будущей супружеской семьи значимо более позитивные по сравнению с оценками родительской семьи. Гендерные различия в представлениях о семье проявились в более позитивных ее оценках девушками. Выявлены как универсальные, так и культурно-специфические особенности образов родительской семьи и образа будущей супружеской семьи у юношей и девушек. Оценки своей родительской и будущей супружеской семьи более позитивные у представителей осетинской культуры по сравнению с оценками представителей русской культуры. Выявлена большая ориентация русских студентов на ценности культуры современного типа по сравнению с предпочтениями осетинских студентов, которые в основном свидетельствуют о большей значимости ценностей традиционной культуры в сфере супружеских отношений.

\section{СПИСОК АИТЕРАТУРЫ}

Абульханова, К. А. (1999) Психология и сознание личности (Проблемы методологии, теории и исследования реальной личности) : Избранные психологические труды. М. : Изд-во Моск. псих.-соц. ин-та ; Воронеж : НПО «МОАЭК». 224 с.

Алмазова, О. В. (2013) Особенности образа взрослого сиблинга [Электр. ресурс]// Психологические исследования. 2013. Т. 6. № 29. С. 3. URL: http://psystudy.ru/index.php/num/ 2013v6n29/828-almazova29.html [архивировано в WebCite] (дата обращения: 12.05.2014).

Артемьева, Е. Ю. (1999) Основы психологии субъективной семантики / под ред. И. Б. Ханиной. М. : Наука ; Смысл. 350 с.

Берри, Аж. В., Пуртинга, А. Х., Сигалл, М. Х., Аасен, П. Р. (2007) Кросс-культурная психология. Исследования и применение. Харьков : Гуманитарный центр. 558 с.

Блос, П. (2010) Психоанализ подросткового возраста : пер. с англ. М. : Ин-т общегуманит. исслед. 272 с.

Бодалев, А. А. (1998) Вершина в развитии взрослого человека, характеристики и условия достижения. М. : Флинта. 99 с.

Брушлинский, А. В. (2003) Психология субъекта / отв. ред. В. В. Знаков. М. : ИзА-во Ин-та психологии РАН ; СПб. : Алетейя. 272 с.

Буровихина, И. А. (2013) Социальная ситуация развития как условие формирования образа мира современного подростка : дис. .... канд. психол. наук. М. 313 с. $182 \mathrm{c}$.

Варга, А. Я. (2009) Введение в системную семейную психотерапию. М. : Когито-Центр.

Верещагина, М. В. (2010) Этническая идентичность и этническая толерантность русских и осетинских студентов : дис. ... канд. психол. наук. Владикавказ. 262 с.

Виничук, Н. В. (2012) Особенности представлений психосоматических больных о счастье [Электр. ресурс] // Психологические исследования. №2 (22). C. 7. URL: http://psystudy. ru/index.php/num/2012n2-22/653-vinichuk22 [архивировано в WebCite] (дата обращения: 12.05.2014).

Гамезо, М. В., Герасимова, В. С., Горелова, Г. Г., Орлова, А. М. (1999) Возрастная психология. Аичность от молодости до старости. М. : Педагог. о-во России ; Изд. дом «Ноосфера». $269 \mathrm{c}$.

Голод, С. И. (1995) Моногамная семья: кризис или эволюция // Социально-политический журнал. №6. С. 74-87.

Аенисова, Т. Н. (2013) Особенности представлений о времени у школьников и студентов с различной выраженностью мотивации достижения // Вестн. Моск. ун-та. Сер. 14. Психология. № 1. С. 111-122.

Ильченко, В. В. (2010) Этнические особенности психосексуального развития девушек в поликультурной среде (на примере Республики Северная Осетия - Алания) : дис. ... канд. психол. наук. СПб. 279 с. 
Ипполитова, Е. А. (2011) Образ семьи в представлениях молодых и зрелых мужчин и женщин в условиях интенсивных социальных изменений // Молодой ученый. № 11-2. С. 70-74.

Калоев, Б. А. (2004) Осетины: Историко-этнографическое исследование. 3-е изд., испр. и перераб. М. : Наука. 471 с.

Кибизова, Э. Э. (1999) Этносоциальные ценности представителей разных поколений (на примере русских и осетин) : дис. ... канд. психол. наук. СПб. 237 с.

Кон, И. С. (1979) Психология юношеского возраста (Проблемы формирования личности) : учеб. пос. для студентов пед. ин-тов. М. : Просвещение. 175 с.

Коновалова, А. М. (2012) Исследование семантики «уважение к родителям» [Электр. ресурс]// Материалы XIX Междунар. науч. конф. студ., аспир. и молодых ученых «Иомоносов2012». URL: http://lomonosov-msu.ru/archive/Lomonosov_2012/1838/21292_32c8.pdf [архивировано в WebCite] (дата обращения: 12.05.2014).

Косаревская, Т. Е., Кутькина, Р. Р. (2009) Психосемантический подход к исследованию индивидуального сознания : метод. рекомендации. Витебск : Витебский гос. ун-т им. П. М. Машерова. $61 \mathrm{c.}$

Манухина, Н. М. (2011) Родители и взрослые дети: Парадоксы отношений. М. : НФ «Класс». 248 c.

Нартова-Бочавер, С. К. (2008) Человек суверенный: психологическое исследование субъекта в его бытии. СПб. : Питер. 400 с.

Перегудина, В. А. (2011) Особенности становления мужской и женской гендерной идентичности в возрастном диапазоне от старшего дошкольного до юношеского возраста : дис. ... канд. психол. наук. Тула. 239 с.

Петренко, В. Ф. (2005) Основы психосемантики. 2-е изд., доп. СПб. : Питер. 480 с.

Петренко, В. Ф., Митина, О. В. (2012) Представления россиян о качестве жизни при разных правительствах // Вестн. РАН. Т. 82. № 2. С. 124-130.

Петровский, А. В., Ярошевский, М. Г. (1998) Основы теоретической психологии. М. : ИНФРА-М. 528 с.

Психология и культура (2003) / под ред. А. Мацумото. СПб. : Питер. 718 с.

Родионова, Н. В. (1996) Семантический дифференциал (обзор литературы) // Социология: 4M. № 7. С. 161-183.

Садовникова, Т. Ю. (2009) Семейные ценности и идентичность в сфере психологической интимности в юношеском возрасте // Четвертая Междунар. науч. конф. «Психологические проблемы современной семьи» 21-23 октября 2009 г., Москва : тезисы конф. / под ред. Е. И. Захаровой, О. А. Карабановой. М. : Изд-во МГУ. 720 с. С. 558-564.

Серкин, В. П. (2004) Методы психосемантики. М. : Аспект Пресс. 207 с.

Сытько, Т. И. (2014) Структура и типы родительско-детских отношений в процессе семейной сепарации : дис. ... канд. психол. наук. М. 213 с.

Теория семейных систем Мюррея Боуэна: Основные понятия, методы и кдиническая практика (2005) / под ред. К. Бейкер, А. Я. Варги. М. : Когито-Центр. 496 с.

Фельдштейн, А. И. (1995) Проблемы возрастной и педагогической психологии. М. : Междунар. пед. акад. 368 с.

Шабельников, В. К. (2006) Предметность и субъектность детерминирующего мира в концепциях психологии // Методология и история психологии. Т. 1. Вып. 1. С. 23-40.

Шмелев, А. Г. (2002) Психодиагностика личностных черт. СПб. : Речь. 480 с.

Barrera, A. M., Blumer, M. L. C., Soenksen, S. H. (2011) Revisiting adolescent separation-individuation in the contexts of enmeshment and allocentrism // The New School Psychology Bulletin. Vol. 8. No. 2. P. 70-82.

Blos, P. (1979) The adolescent passage: developmental issues. N. Y. : International Universities Press. $521 \mathrm{p}$.

Erikson, E. H. (1968) Identity: Youth and crisis. L. : Faber and Faber. 336 p.

Havighurst, R. J. (1972) Developmental tasks and education. 3rd edn. N. Y. : David McKay Co. $119 \mathrm{p}$. 
Haws, W. A., Mallinckrodt, B. (1998) Separation-individuation from family of origin and marital adjustment of recently married couples // The American Journal of Family Therapy. Vol. 26. Issue 4. P. 293-306.

Hoffman, J. A. (1984) Psychological separation of late adolescents from their parents // Journal of Counseling Psychology. Vol. 31. No. 2. P. 170-178.

Kagitcibasi, C. (2005) Autonomy and relatedness in cultural context: Implications for self and family // Journal of Cross-Cultural Psychology. Vol. 36. No. 4. P. 403-422.

Lapsley, D. K., Rice, K. G., Shadid, G. E. (1989) Psychological separation and adjustment to college // Journal of Counseling Psychology. Vol. 36. No. 3. P. 286-294.

Saraiva, L. M., Matos, P. M. (2012) Separation-individuation of Portuguese emerging adults in relation to parents and to the romantic partner // Journal of Youth Studies. Vol. 15. Issue 4. P. 499-517.

Аата поступления: 4.07.2014 г.

USING THE SEMANTIC DIFFERENTIAL METHOD

IN INVESTIGATING THE REPRESENTATIONS OF FAMILY

IN YOUNG MEN AND WOMEN

O. V. Almazova, V. P. Dzukaeva, T. Yu. Sadovnikova

(LOMONOSOV MOSCOW STATE UNIVERSITY)

The article describes the experience of using a modified version of the semantic differential method in researching later adolescents' images of their parental family and a future family of their own. Our research conducted in 2013-14 covered 205 students (61 men and 144 women) from higher and secondary professional institutions, aged from 17 to 24, 108 of whom were ethnic Russians (52.7\%) and 97 Ossetians (47.3\%) (Moscow, Vladikavkaz, Alagir). For the major research methodology, we chose the modified version of the semantic differential method (E. Yu. Artemyeva, V. F. Petrenko). The method of data analysis has been suggested by O. V. Almazova.

As it proved out, students' estimates of the image of their future marital family were significantly more positive than those of the parental family. The ideas of parental and future marital family have been found to possess significant gender and cultural differences. Women are more likely to use emotional characteristics, such as "warm" and "soft". Men more often use characteristics traditionally viewed as masculine, such as "strong". Gender distinctions in the ideas of future marital family led to more positive estimates being given by women rather than men.

We have revealed both invariant and culture-specific features of both types of images as developed by Russian and Ossetian students. Common for both groups was the similarity of semantic profiles of the family images and higher average estimates of "my future marital family" than "our family" (parental). Distinctions between the two groups manifested themselves in the fact that Russian students are more focused on modern-type cultural values, and Ossetian students - on the values of the traditional type of culture (according to J. Townsend).

Keywords: adolescence, family, semantic differential, cross-cultural research, attitude to marriage, image of the parental family, image of future marital family.

\section{REFERENCES}

Abulkhanova, K. A. (1999) Psikbologiia $i$ soznanie lichnosti (Problemy metodologii, teorii $i$ issledovaniia real'noi lichnosti) : Izbrannye psikbologicheskie trudy [Psychology and consciousness of the person (Problems of methodology, theory and investigation into real personality): Selected psychological works]. Moscow, Moscow Psychological and Social Institute Publ. ; Voronezh, "MODEK" RMA. 224 p. (In Russ.). 
Almazova, O. V. (2013) Osobennosti obraza vzroslogo siblinga [Some features of the image of an adult sibling]. Psikbologicheskie issledovaniia, vol. 6, no. 29, pp. 3. [online] Available at: http:// psystudy.ru/index.php/num/2013v6n29/828-almazova29.html [archived in WebCite] (accessed 12.05.2014). (In Russ.).

Artemyeva, E. Yu. (1999) Osnovy psikbologii sub' ektivnoi semantiki [Foundations of the psychology of subjective semantics]/ ed. by I. B. Khanina. Moscow, Nauka Publ. ; Smysl Publ. 350 p. (In Russ.).

Berry, J. W., Poortinga, Y. H., Segall, M. H. and Dasen, P. R. (2007) Kross-kulturnaia psikbologiia. Issledovaniia $i$ primenenie [Cross-cultural psychology: Research and applications]. Kharkov, Gumanitarnyi tsentr Publ. 558 p. (In Russ.).

Blos, P. (2010) Psikboanaliz podrostkovogo vozrasta [On adolescence: A psychoanalytic interpretation]. Moscow, Institute of All Humanities Studies Publ. 272 p. (In Russ.).

Bodalev, A. A. (1998) Vershina $v$ razvitii vzroslogo cheloveka, kbarakteristiki i usloviia dostizheniia [Vertex in the development of an adult, its characteristics and the conditions for achieving]. Moscow, Flinta Publ. 99 p. (In Russ.).

Brushlinskii, A. V. (2003) Psikbologiia sub' ekta [The psychology of subject]/ ed. by V. V. Znakov. Moscow, Publishing House of the Institute of Psychology, RAS ; St. Petersburg, Aleteiia Publ. 272 p. (In Russ.).

Burovikhina, I. A. (2013) Sotsial' naia situatsiia razvitiia kak uslovie formirovaniia obraza mira sovremennogo podrostka [The social situation of development as a condition for building the image of the world in contemporary adolescents] : Diss. ... Candidate of Psychology. Moscow. 313 p. (In Russ.).

Varga, A. Ya. (2009) Vvedenie v sistemnuiu semeinuiu psikboterapiiu [An introduction to systemic family psychotherapy]. Moscow, Kogito-Tsentr Publ. 182 p. (In Russ.).

Vereshchagina, M. V. (2010) Etnicheskaia identichnost' i etnicheskaia tolerantnost' russkikh i osetinskikh studentov [Ethnic identity and ethnic tolerance in Russian and Ossetian students] : Diss. ... Candidate of Psychology. Vladikavkaz. 262 p. (In Russ.).

Vinichuk, N. V. (2012) Osobennosti predstavlenii psikhosomaticheskikh bolnykh o shchast'e [Features of representations of happiness in psychosomatic patients]. Psikbologicheskie issledovaniia, no. 2 (22), p. 7. [online] Available at: http://psystudy.ru/index.php/num/2012n2-22/653vinichuk22 [archived in WebCite] (accessed 12.05.2014). (In Russ.).

Gamezo, M. V., Gerasimova, V. S., Gorelova, G. G. and Orlova, L. M. (1999) Vozrastnaia psikbologiia. Lichnost' ot molodosti do starosti [The psychology of age. Personal identity from youth to old age]. Moscow, Pedagogical Society of Russia ; Noosfera Publ. House. 269 p. (In Russ.).

Golod, S. I. (1995) Monogamnaia sem'ia: krizis ili evoliutsiia [The monogamous family: crisis or evolution]. Sotsial' no-politicheskii zhurnal, no. 6, pp. 74-87. (In Russ.).

Denisova, T. N. (2013) Osobennosti predstavlenii o vremeni u shkol'nikov i studentov s razlichnoi vyrazhennost'iu motivatsii dostizheniia [Features of the notions of time in school and university students with various intensity of achievement motivation]. Vestnik Moskovskogo Universiteta. Seriia 14: Psikhologiia, no. 1, pp. 111-122. (In Russ.).

Ilchenko, V. V. (2010) Etnicheskie osobennosti psikboseksual' nogo razviitiia devushek v polikul'turnoi srede (na primere Respubliki Severnaia Osetiia - Alaniia) [Ethnic aspects of female psychosexual development in multicultural environment (The case of the Republic of North Ossetia - Alania)] : Diss. ... Candidate of Psychology. St. Petersburg. 279 p. (In Russ.).

Ippolitova, E. A. (2011) Obraz sem'i v predstavleniiakh molodykh i zrelykh muzhchin i zhenshchin $\mathrm{v}$ usloviiakh intensivnykh sotsial'nykh izmenenii [The image of the family in the minds of young and mature men and women under the conditions of intense social change]. Molodoi ucbenyi, no. 11-2, pp. 70-74. (In Russ.).

Kaloev, B. A. (2004) Osetiny: Istoriko-etnograficheskoe issledovanie [Ossetians: Historical and ethnographic research]. 3rd edn., revised and corrected. Moscow, Nauka Publ. 471 p. (In Russ.). 
Kibizova, E. E. (1999) Etnosotsialnye tsennosti predstavitelei raznykb pokolenii (na primere russkikb $i$ osetin) [Etnosocial multigenerational values (The case of Russians and Ossetians)] : Diss.... Candidate of Psychology. St. Petersburg. 237 p. (In Russ.).

Kon, I. S. (1979) Psikbologiia iunosheskogo vozrasta (Problemy formirovaniia lichnosti) [Psychology of adolescent age (Problems of personal identity building)] : A study guide for students of pedagogical institutes. Moscow, Prosveshchenie Publ. 175 p. (In Russ.).

Konovalova, A. M. (2012) Issledovanie psikhosemantiki "uvazhenie k roditeliam" [A study of the psychosemantics of "respect for parents"]. In: Materialy XIX Mezbdunarodnoi nauchnoi konferentsii studentov, aspirantov $i$ molodykb uchenykb "Lomonosov-2012" [Proceedings of the $19^{\text {th }}$ International conference for undergraduate and postgraduate students and early career researchers "Lomonosov-2012"]. [online] Available at: http://lomonosov-msu.ru/archive/Lomonosov_2012/1838/21292_32c8.pdf [archived in WebCite] (accessed 12.05.2014) (In Russ.).

Kosarevskaya, T. E. and Kutkina, R. R. (2009) Psikbosemanticheskii podkbod k issledovaniiu individual' nogo soznaniia [A psychosemantic approach to the study of individual consciousness]: Study guidelines. Vitebsk, P. M. Masherov Vitebsk State University Publ. 61 p. (In Russ.).

Manukhina, N. M. (2011) Roditeli i vzroslye deti: Paradoksi otnoshenii [Parents and adult children: Paradoxes of relations]. Moscow, NF “Klass” Publ. 248 p. (In Russ.).

Nartova-Bochaver, S. K. (2008) Chelovek suverennyi: psikbologicheskoe issledovanie sub" ekta $v$ ego bytii [The sovereign man: A psychological study of the subject in his/her being]. St. Petersburg, Piter Publ. 400 p. (In Russ.).

Peregudina, V. A. (2011) Osobennosti stanovleniia muzhskoi i zhenskoi gendernoi identichnosti v vozrastnom diapazone ot starshego doshkol'nogo do iunosheskogo vozrasta [Some features of male and female gender identity building from the senior preschool to adolescence] : Diss. ... Candidate of Psychology. Tula. 239 p. (In Russ.).

Petrenko, V.F. (2005) Osnovy psikbosemantiki [Foundations of psychosemantics]. 2nd edn., enlarged. St. Petersburg, Piter Publ. 480 p. (In Russ.).

Petrenko, V. F. and Mitina, O. V. (2012) Predstavleniia rossiian o kachestve zhizni pri raznykh pravitel'stvakh [Russians' notions of quality of life under different governments]. Vestnik Rossiiskoi akademii nauk, vol. 82, no, 2, pp. 124-130. (In Russ.).

Petrovskii, A. V. and Yaroshevskii, M. G. (1998) Osnovy teoreticheskoi psikbologii [Foundations of theoretical psychology]. Moscow, INFRA-M Publ. 528 p. (In Russ.).

Psikbologiia i kul'tura [Psychology and culture] (2003) / ed. by D. Matsumoto. St. Petersburg, Piter Publ. 718 p. (In Russ.).

Rodionova, N. V. (1996) Semanticheskii differentsial (obzor literatury) [The semantical differential (an overview of literature)]. Sotsiologiia 4M, no. 7, pp. 161-183. (In Russ.).

Sadovnikova, T. Yu. (2009) Semeinye tsennosti i identichnost' v sfere psikhologicheskoi intimnosti v iunosheskom vozraste [Family values and identity in the sphere of psychological intimacy in adolescence]. In: Chetvertaia Mezhdunarodnaia nauchnaia konferentsiia "Psikbologicheskie problemy sovremennoi sem' $i$ " [4th International conference "Psychological Issues of Contemporary Family"]. October 21-23, 2009, Moscow : Proceedings / ed. by E. I. Zakharova and O. A. Karabanova. Moscow. 720 p. Pp. 558-564. (In Russ.).

Serkin, V. P. (2004) Metody psikhosemantiki [Methodology of psychosemantics]. Moscow, Aspect Press. 207 p. (In Russ.).

Sytko, T. I. (2014) Struktura $i$ tipy roditel'sko-detskikb otnoshenii $v$ protsesse semeinoi separatsii [Structure and types of parent-child relations during family separation] : Diss. ... Candidate of Psychology. Moscow. 213 p. (In Russ.).

Teoriia semeinykh sistem Miurreia Bouena: Osnovnye poniatiia, metody i klinicheskaia prakti$k a$ [Murray Bowen's theory of family systems: Main concepts, methods and clinical practice] (2005) / ed. by K. Baker and A. Ya. Varga. Moscow, Kogito-Tsentr Publ. 496 p. (In Russ.).

Feldshtein, D. I. (1995) Problemy vozrastnoi i pedagogicheskoi psikbologii [Problems of aging and pedagogical psychology]. Moscow, International Pedagogical Academy Publ. 368 p. (In Russ.). 
Shabelnikov, V. K. (2006) Predmetnost' i sub" ektnost' determiniruiushchego mira v kontseptsiiakh psikhologii [Objectness and subjectness of the determining world in psychological conceptions]. Metodologiia $i$ istoriia psikbologii, vol. 1, issue 1, pp. 23-40. (In Russ.).

Shmelev, A. G. (2002) Psikbodiagnostika lichnostnykb chert [Psychodiagnostics of personality traits]. St. Petersburg, Rech' Publ. 480 p. (In Russ.).

Barrera, A. M., Blumer, M. L. C. and Soenksen, S. H. (2011) Revisiting adolescent separation-individuation in the contexts of enmeshment and allocentrism. The New School Psychology Bulletin, vol. 8, no. 2, pp. 70-82.

Blos, P. (1979) The adolescent passage: developmental issues. New York : International Universities Press. xvi, $521 \mathrm{p}$.

Erikson, E. H. (1968) Identity: Youth and crisis. London, Faber and Faber. 336 p. $119 \mathrm{p}$.

Havighurst, R. J. (1972) Developmental tasks and education. 3rd edn. New York, David McKay Co.

Haws, W. A. and Mallinckrodt, B. (1998) Separation-individuation from family of origin and marital adjustment of recently married couples. The American Journal of Family Therapy, vol. 26, issue 4, pp. 293-306.

Hoffman, J. A. (1984) Psychological separation of late adolescents from their parents. Journal of Counseling Psychology, vol. 31, no. 2, pp. 170-178.

Kagitcibasi, C. (2005) Autonomy and relatedness in cultural context: Implications for self and family. Journal of Cross-Cultural Psychology, vol. 36, no. 4, pp. 403-422.

Lapsley, D. K., Rice, K. G. and Shadid, G. E. (1989) Psychological separation and adjustment to college. Journal of Counseling Psychology, vol. 36, no. 3, pp. 286-294.

Saraiva, L. M. and Matos, P. M. (2012) Separation-individuation of Portuguese emerging adults in relation to parents and to the romantic partner. Journal of Youth Studies, vol. 15, issue 4, pp. 499-517.

Submission date: 4.07.2014.

Алмазова Ольга Викторовна - аспирант кафедры возрастной психологии факультета психологии Московского государственного университета им. М. В. Аомоносова. Адрес: 125009, Россия, г. Москва, ул. Моховая, д. 9, стр. 11. Тел.: +7 (495) 629-57-52. Эл. адрес: almaz.arg@ gmail.com. Научный руководитель - канд. психол. наук, доц. Г. В. Бурменская.

Азукаева Вероника Петровна - аспирант кафедры возрастной психологии факультета психологии Московского государственного университета им. М. В. Аомоносова. Адрес: 125009, Россия, г. Москва, ул. Моховая, д. 9, стр. 11. Тел.: +7 (495) 629-57-52. Эл. адрес: dzukaeva07@ mail.ru. Научный руководитель - канд. психол. наук, доц. Т. Ю. Садовникова.

Садовникова Татьяна Юрьевна - кандидат психологических наук, доцент кафедры возрастной психологии факультета психологии Московского государственного университета им. М. В. Аомоносова. Адрес: 125009, Россия, г. Москва, ул. Моховая, А. 9, стр. 11. Тел.: +7 (495) 629-57-52. Эл. aspec: tatsadov@yandex.ru

Almazova Olga Viktorovna, Postgraduate Student, Department of Developmental Psychology, Faculty of Psychology, Lomonosov Moscow State University. Postal address: 9/11 Mokhovaya St., 125009 Moscow, Russian Federation. Tel: +7 (495) 629-57-52. E-mail: almaz.arg@gmail.com. Research advisor: Candidate of Psychology, Associate Professor G. V. Burmenskaya.

Dzukaeva Veronika Petrovna, Postgraduate Student, Department of Developmental Psychology, Faculty of Psychology, Lomonosov Moscow State University. Postal address: 9/11 Mokhovaya St., 125009 Moscow, Russian Federation. Tel: +7 (495) 629-57-52.E-mail: dzukaeva07@mail.ru. Research advisor: Candidate of Psychology, Associate Professor T. Yu. Sadovnikova.

Sadovnikova Tatiana Yurievna, Candidate of Psychology, Associate Professor, Department of Developmental Psychology, Faculty of Psychology, Lomonosov Moscow State University. Postal address: 9/11 Mokhovaya St., 125009 Moscow, Russian Federation. Tel: +7 (495) 629-57-52. E-mail: tatsadov@yandex.ru 